\title{
ORGANIZATION OF STUDENTS' RESEARCH WORK IN THE CONDITIONS OF PROVIDING PROFESSIONAL ORIENTATION OF THE EDUCATIONAL PROCESS
}

\author{
Ganna Alieksieieva \\ Berdyansk State Pedagogical University \\ Shmidta Str. 4, Berdyansk, 71110, Ukraine \\ alekseeva@ukr.net,https://orcid.org/0000-0003-3204-3139 \\ Larysa Horbatiuk \\ Berdyansk State Pedagogical University \\ Shmidta Str. 4, Berdyansk, 71110, Ukraine \\ loravas@ukr.net,https://orcid.org/0000000205847708 \\ Nataliya Kravchenko \\ Berdyansk State Pedagogical University \\ Shmidta Str. 4, Berdyansk, 71110, Ukraine \\ natalyvkravchenko@gmail.com, https://orcid.org/0000-0002-9642-5403 \\ Bohdan Kindzer \\ Lviv State University of Physical Culture \\ Tadeusha Koschiushki Str. 11, Lviv, 79000, Ukraine \\ BogdanKindzer@ukr.net,https://orcid.org/0000-0002-7503-4892
}

The article considers the organization of research work of future engineers-teachers in the system of professional training of IT specialists through computer environment design. The contradictions between the usual system of training and the individual creative direction of the future professional activity of the specialist are analysed.

The authors studied the concept of the computer environment, considered its information, software, and didactic component. The practical aspects of the organization of educational and research activities of future specialists, the specialty of which requires further research, in particular using the computer environment as an object of design, are revealed. Its intellectual properties are considered and it is proved that they are a reaction to human actions. The model of knowledge representation in the process of designing a computer environment is described and it is proved that the use of a network model in the form of a graph is the best to reflect the meaning of a holistic image.

Thanks to the network model, the course in the discipline is created by a certain structure of modules, which consist of topics that contain tasks. This presentation of data is inherent in the semantic network, which is a combination of ideas and knowledge retention of the entire learning process in an individual educational trajectory. Thus, it is possible to adjust it depending on the level of effectiveness of the student's mastering the material.

The informational, program and didactic components of the computer environment are substantiated, the basic requirements to the organization of research work of students from the point of view of designing where flexibility is the basic property of a system of management, in particular in questions of realization of various forms of occupations on professional training are revealed.

An example of software implementation of a computer environment with an intuitive interface for working with information content is described. It is substantiated that the proposed principles of organization of research work can also be applied in the organization of research work of students of physical culture and sports profile.

Key words: higher education, engineer-teacher, computer environment. 
2021 Випуск/ Issue 48

\section{А. Н. Алексеева}

Бердянский государственный педагогический университет

ул. Шмидта, 4, г. Бердянск, 71110, Украина

л. В. Горбатюк

Бердянский государственный педагогический университет

ул. Шмидта, 4, г. Бердянск, 71110, Украина

Н. В. Кравченко

Бердянский государственный педагогический университет

ул. Шмидта, 4, г. Бердянск, 71110, Украина

\section{Б. Н. Киндзер}

Львовский государственный университет физической культуры им. Ивана Боберского ул. Тадеуша Костюшки, 11, г. Львов, 79000, Украина

\section{ОРГАНІЗАЦІЯ НАУКОВО-ДОСЛІДНИЦЬКОЇ РОБОТИ СТУДЕНТІВ В УМОВАХ ЗАБЕЗПЕЧЕННЯ ПРОФЕСІЙНОЇ ОРІЄНТАЦІЇ НАВЧАЛЬНОГО ПРОЦЕСУ}

У статті розглянута організація науково-дослідної роботи майбутніх інженерів-педагогів в системі професійної підготовки фахівців IT галузі засобами проектування комп'ютерного середовища. Проаналізовано протиріччя між звичайною системою підготовки і індивідуально-творчим напрямом майбутньої професійної діяльності фахівця. Авторами проведено дослідження поняття комп'ютерного середовища, розглянуто його інформаційну, програмну і дидактичну складову. Виявлені практичні аспекти організації навчально-дослідницької діяльності майбутніх фахівців, спеціальність яких вимагає подальшого дослідження, зокрема засобами комп'ютерного середовища як об'єкта проектування. Розглянуто його інтелектуальні властивості та доведено, що вони $є$ реакцією на дії людини. Описана модель подання знань в процесі проектування комп'ютерної середовища і доведено, що використання саме мережевий моделі у вигляді графа $€$ найкращою для відображення сенсу цілісного образу. Завдяки мережевій моделі курс з дисципліни створюється певною структурою модулів, які складаються з тем, які містять завдання. Таке представлення даних притаманне семантичній мережі, що $є$ об'єднанням уявлень і збережень знань всього навчального процесу в індивідуальну освітню траєкторію. Таким чином, з'являється можливість ії корегування залежно від рівня ефективності опанування студентом матеріалу. Обґрунтовано інформаційна, програмна і дидактична складові комп'ютерного середовища, виявлені основні вимоги до організації науково-дослідницької роботи студентів з точки зору проектування, де гнучкість $€$ основною властивістю системи управління, зокрема в питаннях реалізації різних форм занять з професійної підготовки. Описано приклад програмної реалізації комп'ютерного середовища з наявністю інтуїтивно-зрозумілого інтерфейсу для роботи з інформаційним контентом. Обґрунтовано, що запропоновані принципи організації науково-дослідницької роботи можуть бути також застосовані при організації науково-дослідної роботи студентів фізкультурно-спортивного профілю.

Ключові слова: вища освіта, інженер-педагог, комп'ютерне середовище.

\section{А. Н. Алексеева}

Бердянский государственный педагогический университет

ул. Шмидта, 4, г. Бердянск, 71110, Украина

\section{Л. В. Горбатюк}

Бердянский государственный педагогический университет

ул. Шмидта, 4, г. Бердянск, 71110, Украина

\section{Н. В. Кравченко}

Бердянский государственный педагогический университет

ул. Шмидта, 4, г. Бердянск, 71110, Украина

\section{Б. Н. Киндзер}

Львовский государственный университет физической культуры им. Ивана Боберского ул. Тадеуша Костюшки, 11, г. Львов, 79000, Украина

\section{ОРГАНИЗАЦИЯ НАУЧНО-ИССЛЕДОВАТЕЛЬСКОЙ РАБОТЫ СТУДЕНТОВ В УСЛОВИЯХ ОБЕСПЕЧЕНИЯ ПРОФЕССИОНАЛЬНОЙ ОРИЕНТАЦИИ УЧЕБНОГО ПРОЦЕССА}

В статье рассмотрена организация научно-исследовательской работы будущих инженеров-педагогов в системе профессиональной подготовки специалистов ИТ-отрасли средствами проектирования компьютерной среды. Проанализированы противоречия между обычной системой подготовки и индивидуально-творческим направлением будущей профессиональной деятельности специалиста. Авторами проведено исследование понятия компьютерной среды, рассмотрены его информационную, программную и дидактическую составляющую. Обнаруженные практические аспекты организации учебно-исследовательской деятельности будущих специалистов, специаль- 
ность которых требует дальнейшего исследования, в частности средствами компьютерной среды как объекта проектирования. Рассмотрены его интеллектуальные свойства и доказано, что они являются реакцией на действия человека. Описанная модель представления знаний в процессе проектирования компьютерной среды и доказано, что использование именно сетевой модели в виде графа является лучшей для отображения смысла целостного образа. Благодаря сетевой модели курс по дисциплине создается определенной структурой модулей, состоящих из тем, которые содержат задания. Такое представление данных присуще семантической сети, что представляет объединение представлений и сбережений знаний всего учебного процесса в индивидуальную образовательную траекторию. Таким образом, появляется возможность ее корректировки в зависимости от уровня эффективности освоения студентом материала. Обоснованно информационная, программная и дидактическая составляющие компьютерной среды, выявлены основные требования к организации научно-исследовательской работы студентов с точки зрения проектирования, где гибкость является основным свойством системы управления, в частности в вопросах реализации различных форм занятий по профессиональной подготовке. Описан пример программной реализации компьютерной среды с наличием интуитивно-понятного интерфейса для работы с информационным контентом. Обосновано, что предложенные принципы организации научно-исследовательской работы могут быть также применены при организации научно-исследовательской работы студентов физкультурно-спортивного профиля.

Ключевые слова: высшее образование, инженер-педагог, компьютерная среда.

Problem formulation. Changes taking place in the modern education system, Ukraine's entry into the European educational space, and the growing role of informatization determine the process of modernization of the entire education system. Analysing the process of training students of engineering and pedagogical specialties of computer profile revealed contradictions between the today system of training a future specialist and its future activities, which is characterized by individual creative nature. The existing process of training a computer engineer-teacher focuses mainly on the reproductive style of activity and does not contribute to the formation of a systematic vision of the educational process, the need for creative self-realization, research approach to learning.

Analysis of basic research and publications. The study of the problem of creating a holistic system of computer training was initiated by A. Bork, R. Williams [7], K. McLean [7], S. Papert, B. Hunter [18] and others. In the work of T. Nestorenko the influence of modern information technologies use on the sphere of education is investigated [15]. Main issues related to the implementation the information and communication technologies into the teaching are reflected in the researches of G. Alieksieieva [1; 2], M. Asherov [3], V. Bykov [4], I. Bulakh, O. Dovhialo, M. Zhaldak [10], A. Ostenda [26], Yu. Ramskyi and others; didactic and psychological issues of information and communication technologies implementation into teaching are addressed in works of V. Bezpalko, V. Liaudis, Yu. Maibyts, A. Pyshkalo, O. Spivakovskyi and others. Their professional training is described in the publications of scientists: S. Artiukh, A. Asherov [3], N. Briukhanova and others; from professional point of view the theoretical and methodological principles of training of future engineers-teachers of computer profile are described by R. Gorbatyuk [8], introduction of information and communication technologies in the educational and training process is considered by B. Kindzer [13], but the issues of organization of educational and research activities of students of engineering and pedagogical specialties of computer profile with the computer environment's help need further research.

The article purpose is to study the concept of "computer environment", substantiation of information, software and didactic components of the computer environment, identifying the basic requirements for the computer environment of research work of students of engineering and pedagogical specialties of computer profile as to the object of design.

Presenting main material. Designing a computer environment for research work of students of engineering and pedagogical specialties of computer profile is a rather complex issue that requires the specialists' participation from different science fields. Some of the minimums that should include such an environment are a flexible model for presenting knowledge and scientific information; mechanisms of adaptation under the current user; convenient and functional tools for filling content, viewing it, searching for information [3, c. 86].

It is necessary to take into account the following features of the computer environment. The computer environment provides an opportunity to develop the highest, most productive forms of thinking [3]. The educational and research activities process visualization requires the use of various means of computer graphics. Achievement of 
real student independence is possible with the use of methods of artificial intelligence. The educational environment is focused on independent work but must have certain types of control or logging of user actions [9].

When designing a computer environment, it is necessary to justify the use of a knowledge representation particular model [6]. Based on an empirical approach based on the study of the principles of human memory organization and modelling of mechanisms for solving human problems, it was found that the most optimal for use is a network model of knowledge representation. This means a graph that shows the value of the entire image. Graph nodes correspond to concepts and objects, and arcs - the relationship between objects. When using a network model, the course structure is a set of modules that are divided into topics, and those, in turn, into tasks. Thus, the presentation and storage of knowledge at each course level (modules, topics) is a semantic network. The module is an oriented graph consisting of topics. Each topic is a separate graph consisting of different types of tasks (theoretical, practical, controlling, etc.). The relationships between the vertices of these graphs determine the conditions under which the learning trajectory is built. Relationships between vertices can have the following characteristics: 1 ) the degree of significance: s1 - to study an object it is necessary to have a general idea of another object; s2 - when studying an object, references to another object are used; s3 - to study the most complex (or rarely used) concepts of the object requires knowledge of another object; s4 - for the study of the object and the practical application of knowledge requires a clear knowledge of another object; 2) the coefficient of assimilation of the material is determined based on solving the proposed tasks [7].

All this allows you to combine the entire learning process into a single trajectory, which is adjusted depending on the student's success in mastering the material.

In conditions when the development of the educational process organization is carried out using a computer environment, the need to assess the quality of software and tools, taking into account the analysis of the intellectual properties of the developed software. To assess the intellectual properties of the computer environment, it is necessary to define the concept of an "intelligent educational system", to form appropriate algorithms that can determine how a property classified as intelligent can be detected during the operation of the software [16].

The intellectual properties of the computer environment are manifested as a reaction to certain actions by the user and can be recorded and evaluated as a list or set of parameters, properties, and numerical characteristics, and this reaction must be adequate to the pedagogical situation in which the whole system "user environment + object of educational efforts". The reaction can be expressed as a change in the graphic content of the screen, a text message on the screen, a video or animated fragment, an audio message, a signal, or a set of different reactions of the computer environment.

Following the above, one of the main requirements for the design of a computer environment is the flexibility of the control system and the ability to implement complex structures of training sessions. This is possible taking into account the maximum available number of parameters and factors that provide a substantive dialogue between the student and the computer environment, with user-friendly control methods, controlled navigation, developed interface using software-implemented means of presenting the information [26].

Hypertext as a method of information nonlinear presentation is the most promising in designing a computer environment. But it is necessary to increase the degree of information order. And for this, depending on education, learning objectives, subject taught so on, it is necessary for each computer environment or part thereof to develop a system of link classification that forms an information grid.

The software implementation of the computer environment should include an intuitive interface for working with the information array, which allows us to navigate the space of concepts [10]. The task of finding and sorting information in a computer environment can be solved by contextual processing of information, which is divided into external and internal. Internal contextual processing of information materials in a computer environment allows us to make an objective description of the information unit of the environment [23]. External contextual processing is the formation of links between different information units of the computer environment.

One of the principles of the computer environment pedagogical design is the synergetic principle of diversity, which allows the user, due to the nonlinearity of the hypertext architecture of the computer environment, to find personal knowledge-attractors that structure its knowledge system [11].

The computer environment design as an interconnected and control system is fully consistent with the concept of self-organized processes [17]. They are based on the synergetic principle of subordination, according to which the original 
complex system can be represented as a complex hierarchical system consisting of a set of dynamic subsystems. These subsystems are subordinate to each other, being in a certain dynamic relationship.

When using the computer environment in the educational activities of students of engineering and pedagogical specialties of computer profile, in particular in the process of research work, it is necessary to develop a special method [9]. Spontaneous organization of work in a computer environment is inefficient. Only some of the most developed students can work at the level of awareness of the mode of action, stable target complexes (goal - means - result), and stable cognitive activity. In most cases, the computer environment takes the form of "button" work, cognitive activity does not take a stable form, the work is destroyed at the slightest difficulty, and external obstacles [14; 16]. And here there is an acute shortage of special literature on methods of working in a computer environment, as well as scientific and practical publications on the design and use of a computer environment.

At the same time, there is a poorly controlled flow of "experimental and author's" programs [22]. And this is because there is no single coordination centre, represented by specialists in various fields (general and age psychology, pedagogy, ergonomics, information and communication technologies, medicine, etc.), which would design, develop, license, and create a single database of electronic resources for educational purposes.

The pedagogical software should be included in the didactic system and cover a range of areas, such as the mental processes development; the research work methods formation; acquaintance with future professional activity; design, etc. [10; Ошибка! Источник ссылки не найден.; 18].

The software, which is part of the computer environment of research work of students of engineering and pedagogical specialties of computer profile, must be of high quality from different points of view, this is the process of writing code, using different, depending on the tasks that solved, programming languages and technologies, design, ergonomics, etc [18]. At low quality, the computer environment does not justify hopes for the realization of the developing function of training which to the greatest extent provides the formation of the person and its abilities.

Currently, it is not a complicated and time-consuming process for a specialist to develop and debug software. To implement this, use different programming languages and technologies, there are a large number of ready-made libraries and frame- works for inclusion in your software product. Developing software that is necessary and acceptable for teaching and research work of students of engineering and pedagogical specialties of computer profile is quite a difficult task [19]. The main difficulty that arises for educational software developers is to create scripts that have didactic value. As a rule, programs that are not written by specialists in the field of education, or without consultation with educators, solve rather narrow problems. Also, they are not always based on a certain psychological and pedagogical foundation and do not meet such criteria [21]: conceptual (establishment of psychological mechanisms of interaction between the student and the computer environment in the educational process); technological (interaction of different components and methods of managing the learning process in a computer environment); operational (definition of those functions and ways of their realization which can be put on the computer environment); the level of pedagogical realization (taking into account psychological and pedagogical features of students when solving specific tasks in a computer environment) [3, c. 33].

In the computer environment, there is a new quality of interaction of subjects of the educational process (the student - the computer - virtual communities - scientific communities - the teacher). Appropriate information, technical, mathematical, and software takes the computer environment beyond the educational institution, opens access to new sources of information, equips the student with new means of obtaining, integrating, and understanding [21]. This approach in the computer environment meets the essential needs of the student in obtaining information. The ability to comprehend and systematize the received information, to realize it as a personal achievement comes to the fore [16; 25].

Conclusions. The literature sources analysis on the researched problem allowed to interpret the concept of "computer environment" as the immediate environment of the student and other subjects of the educational process with the use of information and communication technologies that provide favourable conditions of their activity for achievement the cognitive purposes.

The learning process should be proactive and have a strong professional orientation. The growing flow of information, the rapid accumulation of knowledge, the constant development of information and communication technologies make it almost impossible, with the traditional approach, the assimilation of educational material in a short time. Therefore, the use of a computer environ- 
ment in the educational process will increase the speed of perception, the depth of learning, but the intensification of learning should not create mental overload, increase labour costs for both students and teachers. The use of computer environment should also be introduced in the organization of research work of students of physical culture and sports, which is planned to do to improve the research work of students of Lviv State University of Physical Culture named after Ivan Boberskij and
Berdyansk State Pedagogical University. We have to note the need to create a computer environment with improved, ergonomic characteristics, software components, integration with other electronic educational resources, etc., which would minimize intellectual effort, independence of cognition, increase cognitive activity, and, ultimately, a quality research component professional competence of future specialists.

\section{СПИСОК ВИКОРИСТАНИХ ДЖЕРЕЛ ТА ЛІТЕРАТУРИ:}

1. Алєксєєва Г. М. Формування готовності майбутніх соціальних педагогів до застосування комп'ютерних технологій у професійній діяльності, Монографія. Донецьк: ЛАНДОН-XXI, 2014. 269 с.

2. Алєксєєва Г. М. Використання інформаційно-комунікаційних технологій в процесі професійної підготовки студентів педагогічних вузів. Актуальні питання природничо-математичної освіти. 2014. С.184-191.

3. Ашеров А. Т., Горбатюк Л. В. Организация самостоятельной работы будущих инженеров педагогов компьютерного профиля: состояние проблемы. Проблеми інженерно-педагогічної освіти. 20 (2008). 8493.

4. Березовська Л. І. Формування комунікативно-мовленнєвої компетентності майбутніх соціальних працівників засобами інтерактивних технологій. Актуальні питання гуманітарних наук. Вип. 27. Том 1. 2020. С. 139-145.

5. Биков В. Ю. Відкрита освіта в Єдиному інформаційному освітньому просторі. Педагогічний дискурс. 2010. №. 7. С. 30-35.

6. Бучківська Г. В. Використання інформаційно-комунікаційних технологій у процесі художньо-трудової діяльності майбутніх учителів початкових класів. Наукові записки Тернопільського національного педагогічного університету імені Володимира Гнатюка. Серія: Педагогіка. Тернопіль: Вид. відділ ТНПУ, 2018. № 1. С. 39-46. DOI: https://doi.org/10.25128/2415-3605.18.1.6

7. Вильямс Р., Маклин К. Компьютеры в школе. Москва : Прогресс, 1988. 336 с.

8. Горбатюк Р. М. Теоретико-методичні засади професійної підготовки майбутніх інженерів-педагогів комп'ютерного профілю : дис. Тернопільський національний педагогічний університет імені Володимира Гнатюка, 2011.

9. Гура В.В. Теоретические основы педагогического проектирования личностно-ориентированных электронных образовательных ресурсов и сред. Ростов н/Д: Изд-во Южного федерального ун-та, 2007. $320 \mathrm{c}$.

10. Жалдак М. І., Лапінський В. В., Шут М. І. Комп’ютерно-орієнтовані засоби навчання математики, фізики, інформатики: Посібник для вчителів Київ : Дініт. 2004.

11. Жук Ю. О., Биков В. Ю.. Засоби навчання нового покоління в комп’ютерно орієнтованому навчальному середовищі. Комп'ютер в школі та сімї. 2005. 5, С. 20-24.

12. Лапінський, В. Навчальне середовище нового покоління та його складові. Науковий часопис НПу імені М. П. Драгоманова. Серія 2. Комп'ютерно-орієнтовані системи навчання. 2008.6 (13). С. 26-32.

13. Кіндзер Б. Використання сучасних комп'ютерних та цифрових технологій у навчальній (тренерській), викладацькій та змагальній діяльності в східних одноборствах (на прикладі Кіокушин карате). Теорія та методика фізичного виховання . 2007. № 8. С. 41-44.

14. Колос К. Р. Модель процесу та критерії добору компонентів комп'ютерно орієнтованого навчального середовища закладу післядипломної педагогічної освіти. Інформаційні технології в освіті. 2013. (17). C.109-117.

15. Несторенко Т.П. «Економіка суперзірок»: можливості та загрози для сфери освіти. Український журнал прикладної економіки. 2020. Том 7. № 2. С. 8-15.

16. Овсянніков О. С. Сутнісні характеристики комп'ютерного середовища Науковий вісник Національного університету біоресурсів і природокористування України. Серія «Педагогіка. Психологія. Філософія. 2012. Вип. 175 (2). С. 233-240.

17. Петіна Л. В. Шляхи удосконалення внутрішньогосподарської звітності та перманентної інвентаризації в прийнятті управлінських рішень на підприємствах АПК. Науково-виробничий журнал Бізнес-Навігатор. 2009. №2 (17). С. 147-151. 
18. Ступак О. Ю. Рейтингове оцінювання діяльності науково-педагогічних працівників якості освітніх послуг. Засоби навчальної та науково-дослідної роботи. 2016. Вип. 46. С. 69-76.

19. Тарануха О. М., Амеліна Н. К., Клименко І. С. Тенденції розвитку ринку консалтингових послуг в Україні. Економіка та управління на транспорті. 2017. Вип. 4. С.129-134.

20. Хантер Б. Рекомендации по использованию информационных технологий Москва : Просвещение. 2006. $145 \mathrm{c}$.

21. Cherniavskyi V., Popova H., Voloshynov S., Sherman M., Yurzhenko A.. Mixed reality technologies as tool to form professional competency of sea transport professionals. ICTERI-2020, Proceedings of the 16th International Conference on ICT in Research, Education and Industrial Applications. Kharkiv, Ukraine, October 6-10, 2020 / Edited by Vadim Ermolayev, Frédéric Mallet, Vitaliy Yakovyna, Vyacheslav Kharchenko, Vitaliy Kobets, Artur Korniłowicz, Hennadiy Kravtsov, Mykola Nikitchenko, Serhiy Semerikov, Aleksander Spivakovsky. pp. $217-231$.

22. Doronina O., Karpenko A. Human Potential and Innovation as Drivers of Competitiveness in the New Economy. Roczniki Ekonomiczne Kujawsko-Pomorskiej Szkoły Wyższej w Bydgoszczy. 2019. no. 12ю pp. 71-81.

23. Havrysh N., Zdanevych L., Myskova N. Pedagogical training as a form of preparing the future professionals `of preschool education / Innovative Approaches to Ensuring the Quality of Education, Scientific Research and Technological Processes / Edited by Magdalena Gawron-Łapuszek, Yana Suchukova. Monograph 43. Publishing House of University of Technology, Katowice, 2021. pp. 244-250.

24. Kravchenko N. V., Alyeksyeyeva H.M., Gorbatyuk L.V. Curriculum Optimization by the Criteria of Maximizing Professional Value and the Connection Coefficient of Educational Elements, Using Software Tools: (ICTERI 2018: 14th International conference on ICT in education, research, and industrial applications) (Kyiv, Ukraine, May 1417, 2018). CEUR Workshop Proceedings, 2018, Vol.1, pp. 365-378.

25. Lavrik V., Cortez L., Alekseeva A., García G. T., Juarez P. G., Poblano J. Development of the CAD system for designing non-standard constructions from elastomers. Development. 2014. 3(3). pp. 10717-10726

26. Lysenkova I. P. Correction-Developing Environment as a Means of Emotional Development of Children with Cognitive Impairment. The Norwegian Journal of Development of the International Science. 2018. no. 20, Vol. 2, pp. 67-69.

27. Ostenda A., Nestorenko T., Ostenda J. Practical education on a higher level in Poland: example of Katowice School of Technology. Scientific papers of Berdyansk State Pedagogical University Series: Pedagogical sciences. 2018. vol. 1. pp.186-190.

\section{REFERENCES:}

1. Alieksieieva, H.M. (2014). Formuvannia hotovnosti maibutnikh sotsialnykh pedahohiv do zastosuvannia kompiuternykh tekhnolohii u profesiinii diialnosti [Formation of readiness of future social educators to use computer technologies in professional activity], Monohrafiya. Donecz`k: LANDON -XXI, 269 s. (in Ukrainian).

2. Alieksieieva, H.M. (2014). Vykorystannia informatsiino-komunikatsiinykh tekhnolohii v protsesi profesiinoi pidhotovky studentiv pedahohichnykh vuziv [Victorious information-communal technologies in the process of professional training of students of pedagogical universities]. Aktual'ni pytannya pryrodnycho-matematychnoyi osvity. Sumy, Ukrayina: VVP «Mriya», pp.184-191. (in Ukrainian).

3. Asherov, A.T. \& Gorbatyuk L.V. (2008). Organizatsiya samostoyatelnoy raboty budushchikh inzhenerov pedagogov kompyuternogo profilya: sostoyanie problemy [Organization of independent work of future engineers of computer teachers: state of the problem], Problemi Inzhenerno-pedagogichnoyi osviti, no.20, pp.84-93. (in Russian).

4. Berezovska, L. (2020). Formation of communicative and speech competence of future social workers by means of interactive technologies. Aktualni pytannia humanitarnykh nauk. no. 27, T. 1, pp. 139-145. (in Ukrainian).

5. Bykov, V.Yu. (2010). Vidkryta osvita v Yedynomu informatsiinomu osvitnomu prostori [Open education in the Unified Information Educational Space], Pedahohichnyi dyskurs, no.7, pp. 30-35. (in Ukrainian).

6. Buchkivska G. (2018). The use of information and communication technologies in the process of artistic and labor activities of future primary school teachers. Naukovi zapysky Ternopilskoho natsionalnoho pedahohichnoho universytetu imeni Volodymyra Hnatiuka. Seriia: Pedahohika. Ternopil: Vyd. viddil TNPU. № 1. pp. 39-46. DOI: https://doi.org/10.25128/2415-3605.18.1.6 (in Ukrainian).

7. Vilyams, R. \& Maklin, C. (1988). Kompyuteryi v shkole [Computers at school], Progress. 336 p. (in Russian).

8. Horbatiuk, R.M. (2011). Teoretyko-metodychni zasady profesiinoi pidhotovky maibutnikh inzheneriv-pedahohiv kompiuternoho profiliu [Theoretical and methodical principles of professional training of future engineersteachers of a computer profile]: dys. Ternopilskyi natsionalnyi pedahohichnyi universytet imeni Volodymyra Hnatiuka. (in Ukrainian).

9. Gura, V.V. (2007). Teoreticheskie osnovyi pedagogicheskogo proektirovaniya lichnostno-orientirovannyih elektronnyih obrazovatelnyih resursov i sred [Theoretical foundations of pedagogical design of student- 
centered electronic educational resources and environments], Rostov n/D: Izd-vo Yuzhnogo federalnogo un-ta, 320 p. (in Russian).

10. Zhaldak, M.I., Lapinskyi, V.V., Shut, M.I. (2004). Kompiuterno-oriientovani zasoby navchannia matematyky, fizyky, informatyky [Computer-oriented means of teaching mathematics, physics, computer science]: Posibnyk dlia vchyteliv, Dinit. (in Ukrainian).

11. Zhuk, Yu.O., Bykov, V.Yu. (2005). New generation teaching aids in a computer-based learning environment. Komp'yuter v shkoli ta sim'yi, 5, 20-24.

12. Lapins'kyi, V.V. (2008). Navchalne seredovyshche novoho pokolinnia ta yoho skladovi [The learning environment of the new generation and its components]. Naukovyi chasopys NPU imeni M.P. Drahomanova. Seriia 2. Kompiuterno-oriientovani systemy navchannia. 6 (13). S. 26-32.

13. Kindzer, B.M., Kindzer, G.B. (2007). The use of modern computer and digital technologies in educational (coaching), teaching and competitive activities in martial arts (on the example of Kyokushin karate). Theory and methods of physical education. № 8. pp. 41-44.

14. Kolos, K.R. (2013). Process model and criteria for selection of components of computer-oriented educational environment of postgraduate pedagogical education institution. Informacijni texnologiyi v osviti, (17), pp.109-117.

15. Nestorenko, T.P. (2020). The Superstar Economy: Opportunities and Threats for Education. Ukrayinskyj zhurnal pry'kladnoyi ekonomiky.T. 7. № 2. Pp.8-15. (in Ukrainian).

16. Ovsiannikov, O.S. (2012). Sutnisni kharakterystyky kompiuternoho seredovyshcha [Essential characteristics of the computer environment] Naukovyi visnyk Natsionalnoho universytetu bioresursiv i pryrodokorystuvannia Ukrainy. Seriia «Pedahohika. Psykholohiia. Filosofiia», Vyp. 175, no. 2, pp. 233-240. (in Ukrainian).

17. Petina, L.V. (2009). Shlyakhy udoskonalennya vnutrishn'ohospodars'koyi zvitnosti ta permanentnoyi inventaryzatsiyi v pryynyatti upravlins'kykh rishen' na pidpryyemstvakh APK [Ways to improve internal reporting and permanent inventory in management decisions at agricultural enterprises]. Naukovo-vyrobnychyy zhurnal Biznes-Navihator [Research and production magazine Business Navigator]. vol 2 (17). pp. 147 - 151. (in Ukrainian).

18. Stupak, O.Iu. (2016). Reitynhove otsiniuvannia diialnosti naukovo-pedahohichnykh pratsivnykiv yakosti osvitnikh posluh. Zasoby navchalnoi ta naukovo-doslidnoi roboty. Vyp. 46, pp. 69-76. (in Ukrainian).

19. Taranukha O.M., Amelina N.K., Klimenko I.S. (2017). Trends in the market of consulting services in Ukraine. Economics and management of transport. Kyiv: NTU. issue 4. pp.129-134. (in Ukrainian).

20. Hanter, B. (2006). Rekomendatsii po ispolzovaniyu informatsionnyih tehnologiy [Recommendations for the use of information technology], Prosveschenie. (in Russian).

21. Cherniavskyi, V., Popova, H., Voloshynov, S., Sherman, M., Yurzhenko, A. (2020). Mixed reality technologies as tool to form professional competency of sea transport professionals. ICTERI-2020, Proceedings of the 16th International Conference on ICT in Research, Education and Industrial Applications. Kharkiv, Ukraine, October 6-10, 2020 / Edited by Vadim Ermolayev, Frédéric Mallet, Vitaliy Yakovyna, Vyacheslav Kharchenko, Vitaliy Kobets, Artur Korniłowicz, Hennadiy Kravtsov, Mykola Nikitchenko, Serhiy Semerikov, Aleksander Spivakovsky. pp. 217-231.

22. Doronina, O., Karpenko, A. (2019). Human Potential and Innovation as Drivers of Competitiveness in the New Economy. Roczniki Ekonomiczne Kujawsko-Pomorskiej Szkoły Wyższej w Bydgoszczy. no. 12, pp. 71-81. (in Ukrainian).

23. Havrysh, N., Zdanevych, L., Myskova, N. (2021). Pedagogical training as a form of preparing the future professionals `of preschool education / Innovative Approaches to Ensuring the Quality of Education, Scientific Research and Technological Processes / Edited by Magdalena Gawron-Łapuszek, Yana Suchukova. Monograph 43. Publishing House of University of Technology, Katowice. pp. 244-250. (in Ukrainian).

24. Kravchenko, N.V., Alyeksyeyeva, H.M., Gorbatyuk, L.V. (2018). Curriculum Optimization by the Criteria of Maximizing Professional Value and the Connection Coefficient of Educational Elements, Using Software Tools: (ICTERI 2018: 14th International conference on ICT in education, research, and industrial applications) [Електронний ресурс] (Kyiv, Ukraine, May 14-17, 2018). CEUR Workshop Proceedings, Vol.1, pp. 365-378. (in Ukrainian).

25. Lavrik, V., Cortez, L., Alekseeva, A., García G.T., Juarez P.G., Poblano J. (2014). Development of the CAD system for designing non-standard constructions from elastomers. Development, 3(3).

26. Lysenkova, I.P. Correction-Developing Environment as a Means of Emotional Development of Children with Cognitive Impairment. The Norwegian Journal of Development of the International Science. 2018, no. 20, Vol. 2, pp. 67-69. (in Ukrainian).

27. Ostenda, A., Nestorenko, T., Ostenda, J. (2018). Practical education on a higher level in Poland: example of Katowice School of Technology. Naukovi zapysky Berdyanskoho derzhavnogo pedahohichneho universytetu. Seriia: Pedahohichni nauky: zb. nauk. prac. Vol.1. BDPU, pp.186-190. (in English). 